\title{
Gyrodactylus aff. mugili Zhukov, 1970 (Monogenoidea: Gyro- dactylidae) from the gills of mullets (Mugiliformes: Mugilidae) collected from the inland waters of southern Iraq, with an evalutation of previous records of Gyrodactylus spp. on mullets in Iraq
}

\author{
Delane C. Kritsky ${ }^{1}$, Atheer H. Ali ${ }^{2}$ and Najim R. Khamees ${ }^{2}$ \\ ${ }^{1}$ Health Education Program, School of Health Professions, Idaho State University, Pocatello, Idaho, USA; \\ ${ }^{2}$ Department of Fisheries and Marine Resources, College of Agriculture, University of Basrah, Basrah, Iraq
}

\begin{abstract}
Gyrodactylus aff. mugili Zhukov, 1970 (Monogenoidea: Gyrodactylidae) is recorded and described from the gill lamellae of 11 of 35 greenback mullet, Chelon subviridis (Valenciennes) (minimum prevalence 31\%), from the brackish waters of the Shatt Al-Arab Estuary in southern Iraq. The gyrodactylid was also found on the gill lamellae of one of eight Speigler's mullet, Valamugil speigleri (Bleeker), from the brackish waters of the Shatt Al-Basrah Canal (minimum prevalence 13\%). Fifteen Klunzinger's mullet, Liza klunzingeri (Day), and 13 keeled mullet, Liza carinata (Valenciennes), collected and examined from southern Iraqi waters, were apparently uninfected. The gyrodactylids from the greenback mullet and Speigler's mullet were considered to have affinity to $G$. $m u$ gili Zhukov, 1970, and along with G. mugili may represent members of a species complex occurring on mullets in the Indo-Pacific Region. A single damaged gyrodactylid from the external surfaces of the abu mullet, Liza abu (Heckel), was insufficient for species identification. Previously identified species of Gyrodactylus recorded on L. abu in Iraq by various authors were considered possible misidentifications or accidental infections.
\end{abstract}

Keywords: Gyrodactylidea, Gyrodactylus mugili, species complex, Chelon subviridis, Liza abu, Liza carinata, Liza klunzingeri, Valamugil speigleri, mullets, Asia, Shatt Al-Arab River, Shatt Al-Arab Estuary

The Mugilidae (Mugiliformes), comprising 17 genera and 72 valid species commonly called mullets or grey mullets (Eschmeyer and Fong 2013, Froese and Pauly 2013), includes mostly marine and brackish-water coastal fishes occurring in tropical and temperate seas worldwide. Mullets are euryhaline, with many species moving into freshwater from marine habitats for short periods. Only one, the abu mullet, Liza abu (Heckel), of southwestern Asia (Iraq, Iran, Pakistan, Turkey and Syria) is restricted to fresh and brackish waters (Thomson 1997, Froese and Pauly 2013). Mullets are herbivorous and/or detritivorous fishes, feeding on algae, diatoms and small invertebrates associated with algae, and detritus obtained from bottom muds and sands (Coad 2010). In southern Iraq, mullets, particularly L. abu, Klunzinger's mullet, Liza klunzingeri (Day), and greenback mullet, Chelon subviridis (Valenciennes), are commercially fished and comprise economically important local food sources (Coad 2010).

Investigations into the polyonchoinean parasites (Monogenoidea) of mullets have focused primarily on those occurring on their gill lamellae; about 50 species of
Ligophorus Euzet et Suriano, 1977 (Dactylogyridea: Dactylogyridae) have been recorded from these hosts worldwide (see Dmitrieva et al. 2012, Soo and Lim 2012 and references therein), whereas the records of other dactylogyrids on mullets in Iraq and India apparently represent accidental infestations or erroneous identifications (Tripathi 1959, Al-Daraji 1995, Abdul-Rahman 1999, Mhaisen et al. 2003a, Bannai et al. 2005).

Only five species of Gyrodactylus von Nordmann, 1832 (Polyonchoinea: Gyrodactylidea: Gyrodactylidae) have been described from mullets. These include Gyrodactylus zhukovi Ling, 1962 and Gyrodactylus mugili Zhukov, 1970 from so-iuy mullet, Mugil soiuy Basilewsky, now Liza haematocheila (Temminck et Schlegel), from China and the Sea of Japan, respectively; Gyrodactylus mugelus Rawson, 1973 from flathead grey mullet, Mugil cephalus Linnaeus, from off the Georgia coast of the United States; Gyrodactylus curemae Conroy et Conroy, 1985 from white mullet, Mugil curema Valenciennes, from off the coast of Venezuela; and Gyrodactylus xiamenensis Yang et Liu, 2001 from largescale mullet, Liza macrolepis 


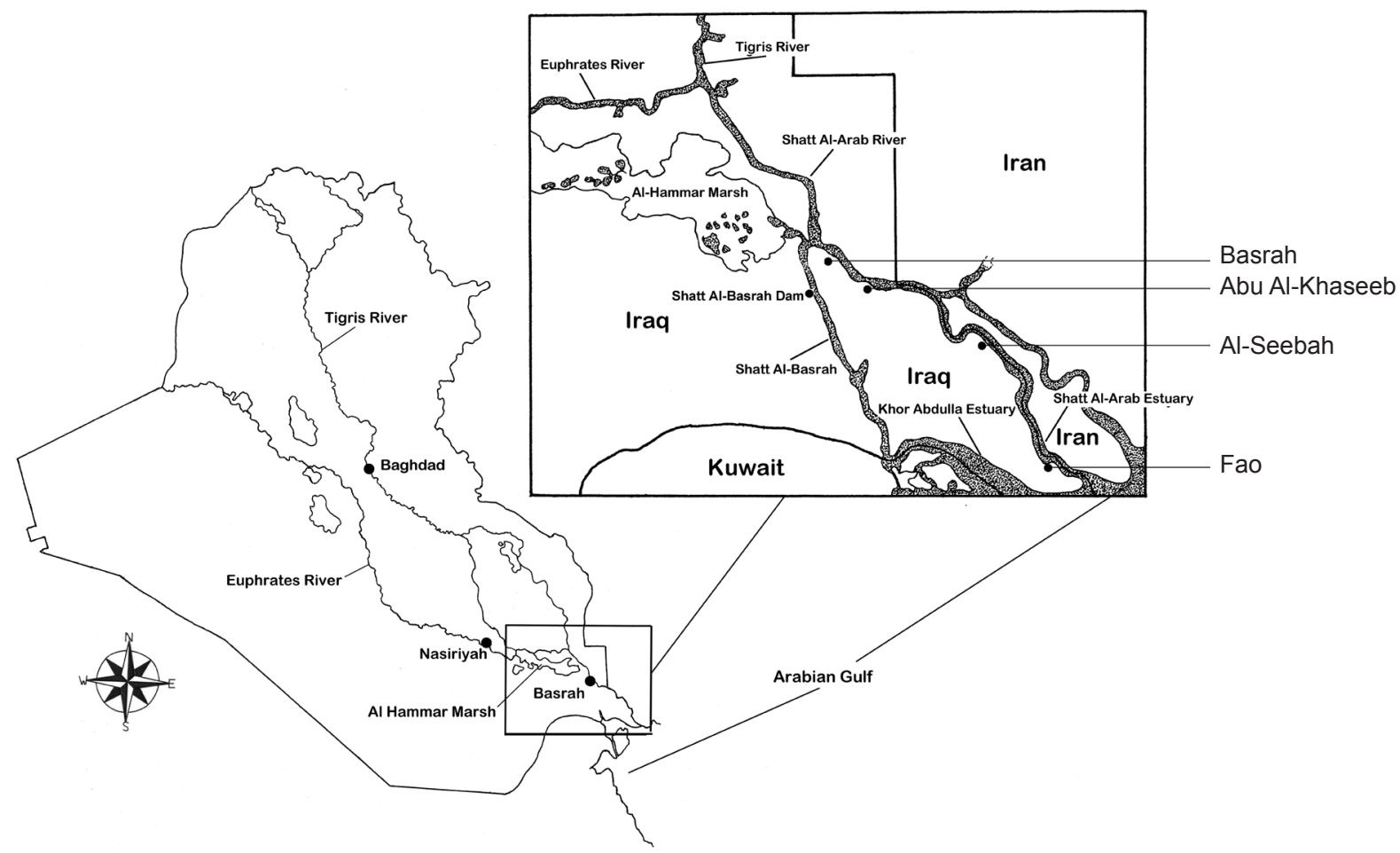

Fig. 1. Map of Iraq and insert showing localities, Basrah (Al-Ashar), Abu Al-Khaseeb (Naher Khooz), Al-Seebah and Fao, and the dam on the Al-Basrah Canal from which mullets were collected.

(Smith), now Chelon macrolepis (Smith), from Fujian Province, China (see Zhukov 1970, Rawson 1973, Conroy and Conroy 1985, Zhang et al. 2001).

Four nominal species of Gyrodactylus that were originally described from other host species have been recorded as parasites of mullets in Iraq. Gyrodactylus baicalensis Bogolepova, 1950, originally described from the abyssocottid, Limnocottus godlewskii (Dybowski) and the cottocomephorid, Batrachocottus multiradiatus Berg (both Scorpaeniformes), was reported on $L$. abu by Mhaisen et al. (1995), Mohammad-Ali et al. (1999) and Balasem et al. (2002). Gyrodactylus vicinus Bychowsky, 1957, originally described from Phoxinus phoxinus (Linnaeus) and Schizothorax intermedius McClelland, now Schizopyge curvifrons (Heckel) (both Cypriniformes, Cyprinidae), and Gyrodactylus menschikowi Gvosdev, 1950, originally described from Barbatula barbatula (Linnaeus) (Cypriniformes: Nemacheilidae), were reported from abu mullet in Iraq by Al-Nasiri et al. (2003) and Al-Zubaidy (2007), respectively. Finally, Gyrodactylus elegans von Nordmann, 1832, a catch-all taxon with Abramis brama (Linnaeus) (Cypriniformes: Cyprinidae) as its type host, has been frequently reported from Iraq on $L$. abu (Ali and Shaaban 1984, Ali 1985, Mhaisen et al. 1995, 2003b, Mohammad-Ali et al. 1999, Al-Awadi 2003, Al-Nasiri et al. 2003, Al Sa'adi 2007, Al-Awadi et al. 2010).

In view of the comparatively high host-specificity exhibited by species of Gyrodactylus on related host groups (Bakke et al. 1992), it is unlikely that these previously described Gyrodactylus spp. occur as natural parasites of mullets (Mugiliformes), which suggest that these records either represent misidentifications or accidental infections. Unidentified species of Gyrodactylus sp. have also been recorded on abu and greenback mullets in Iraq (AlSalim and Jori 2000, Al-Janae'e 2010) and may be the same form recognized herein as Gyrodactylus aff. mugili Zhukov, 1970.

During surveys of polyonchoineans infecting various fishes from fresh and brackish water habitats associated with the Shatt Al-Arab river and estuary in southern Iraq, specimens assignable to Gyrodactylus were collected from three of five species of mullets. Except for a single damaged gyrodactylid found on the abu mullet, the specimens from southern Iraqi waters were considered to have affinity with G. mugili. The latter gyrodactylids are described herein as $G$. aff. mugili based on material collected from the greenback mullet.

\section{MATERIALS AND METHODS}

Five species of mullets were examined for gyrodactylids from fresh and brackish water in southern Iraq. Mullets included the abu mullet, greenback mullet, Klunzinger's mullet, keeled mullet, Liza carinata (Valenciennes), and Speigler's mullet, Valamugil speigleri (Bleeker). Fishes were collected by local fishermen using gill or cast nets from various localities along the Shatt Al-Arab River and Estuary and near the dam on the Shatt Al-Basrah Canal from March 2011 to October 2012 (Fig. 1). 
Fish were immediately killed with a blow to the head, after which the gill baskets were removed and placed in vials containing hot $\left(60^{\circ} \mathrm{C}\right) 5 \%$ formalin $(2 \%$ formaldehyde) solution. The vials were then shaken vigorously for 15-30 sec and labeled. In addition, some entire specimens of abu and greenback mullets were placed in containers containing hot $5 \%$ formalin; containers were vigorously shaken for about two min to remove gyrodactylids from the skin, after which the contents were allowed to settle, the clear liquid decanted and the sediment placed in smaller labeled containers, and along with those containing the gill arches, shipped to Idaho State University for study. Some helminths, picked from the sediments with a fine probe under low-magnification microscopy, were mounted unstained on microscope slides in Gray and Wess medium for study of sclerotized structures; other specimens were stained with Gomori's trichrome and mounted in Canada balsam on a slide for examination of soft anatomy (Kritsky et al. 1978, Humason 1979).

Illustrations were prepared with the aid of a camera lucida or microprojector. Measurements, all in micrometres, were obtained using a calibrated filar micrometer mounted on a phasecontrast microscope and were represented by straight-line distances between extreme points. They were expressed as the mean followed by the range and number (n) of structures measured in parentheses; body length included also that of the haptor. Haptoral terminology was that of Mizelle and Kritsky (1967) and Kritsky and Mizelle (1968). Scientific and common names of fishes were those listed in FishBase (Froese and Pauly 2013) and verified in Eschmeyer (2013).

Helminth specimens were deposited in United States National Parasite Collection (USNPC), Beltsville, Maryland; the University of Nebraska State Museum, Harold W. Manter Laboratory (HWML), Lincoln, Nebraska; the Natural History Museum (NHMUK), London, United Kingdom; and the helminth collection of the Institute of Parasitology, Academy of Sciences of the Czech Republic (IPCAS), České Budějovice, Czech Republic, as indicated in the taxonomic account.

Minimum prevalence, used herein to indicate the size of the infected segment of the host population, is defined as the smallest proportion of examined hosts (mullets) infected with gyrodactylids. This concept reflects the real possibility that gyrodactylids might have been missed during examination of sediments obtained from individual fishes due to the difficulty in finding the small, colourless and transparent worms within the detritus. When intensities are low, as they apparently were in most of the fishes examined, some hosts determined to be negative for gyrodactylids may have had an undetected low-level infection, which would have resulted in observed prevalences that were lower than actual levels.

\section{RESULTS}

Five species of mullets were examined from the fresh and brackish waters of southern Iraq. Gyrodactylids were collected from the gill lamellae of 11 of 35 Chelon subviridis (minimum prevalence $31 \%$ ) from the Shatt Al-Arab Estuary near Fao on 31 March 2012 (salinity 25.3 ppt); two C. subviridis collected from the Shatt Al-Basrah Canal near the dam on 19 September 2012 (salinity 23.8 ppt) and nine from the Shatt Al-Arab River near Naher Khooz (within the city of Abu Al-Khaseeb) on 27 August 2012 (salinity $5.0 \mathrm{ppt}$ ) were apparently uninfected. Gills of one of eight Valamugil speigleri (minimum prevalence 13\%) from the Shatt Al-Basrah Canal (19 September 2012; salinity $23.8 \mathrm{ppt}$ ) were infected.

Gyrodactylids were not found on three $V$. speigleri from the Shatt Al-Arab Estuary near Fao (4 September 2012; salinity $31.1 \mathrm{ppt}$ ), five Liza klunzingeri from the Shatt Al-Arab River near Naher Khooz, Abu Al-Khaseeb (27 August 2012; salinity 5 ppt), five L. klunzingeri from the Shatt Al-Arab River at Ashar, the centre of Basrah (25 August 2012; salinity 2.3 ppt), five L. klunzingeri from the Shatt Al-Arab Estuary near Fao (4 September 2012; salinity $31.1 \mathrm{ppt}$ ), and 13 Liza carinata from the Shatt Al-Basrah Canal (29 August 2012; salinity 23.4). A single gyrodactylid (USNPC 106946) was found within the skin washings of Liza abu collected on 19 September 2011 from the Shatt Al-Arab River near Seebah (salinity $2.5 \mathrm{ppt})$.

Although the original description of Gyrodactylus mugili Zhukov, 1970 is insufficient to identify the species with certainty, all gyrodactylids collected during the present study, with the exception of the specimen from L. $a b u$, were considered to have affinity to this species, based on the comparative morphology of the anchor/bar complexes of present specimens with the respective figure (Fig. 4a) in Zhukov (1970). The specimen from the external surfaces of $L . a b u$ was damaged and insufficient for identification.

Class Monogenoidea Bychowsky, 1937

Subclass Polyonchoinea Bychowsky, 1937

Order Gyrodactylidea Bychowsky, 1937

Gyrodactylidae van Beneden et Hess, 1863

\section{Gyrodactylus aff. mugili Zhukov, 1970}

Figs. 2-7

Description (based on 33 [19 stained] specimens from Chelon subviridis; measurements in Table 1): Body proper fusiform; greatest width usually at level of uterus when containing embryo; peduncle short, tapering toward haptor.

Cephalic lobes poorly to well developed, each containing large head organ, inconspicuous spike sensilla. Cephalic glands comprising bilateral groups of unicellular glands posterolateral to pharynx; prepharyngeal cephalic glands not observed. Pharynx having two tandem subequal bulbs, pharyngeal papillae inconspicuous; oesophagus short; intestinal caeca nonconfluent, extending slightly posterior to testis, with moderately thick walls.

Testis with flattened anterior margin abutting posterior margin of germarium. Proximal portion of vas deferens, seminal vesicle and prostates not observed. Male copulatory organ lying to right or left of body midline, armed with large spine and four to six (usually five) spinelets; medial spinelets smaller than lateral spinelets.

Germarium subspherical, containing large oocyte surrounded by thin peripheral layer of germinal cells; ovi- 

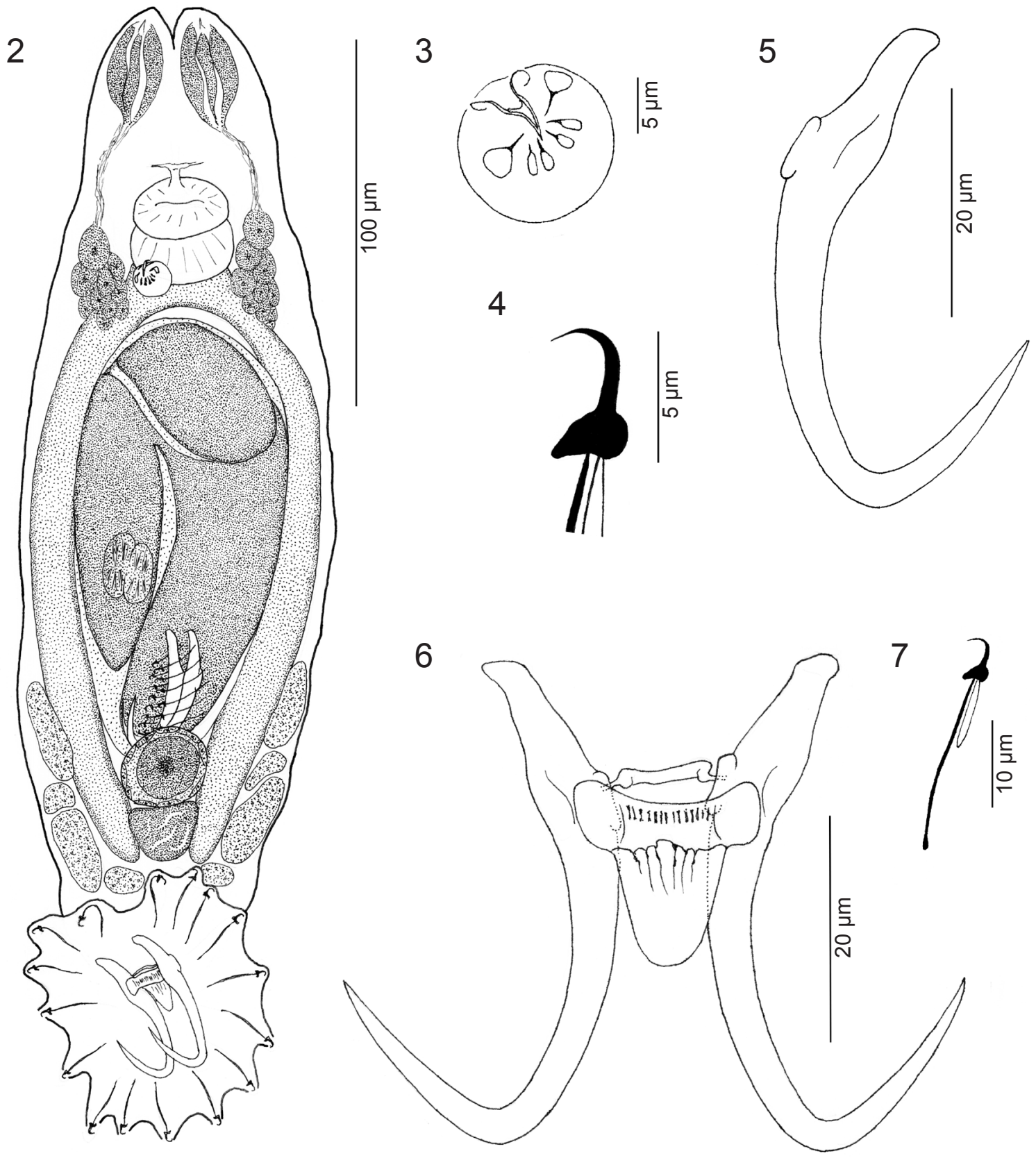

Figs. 2-7. Gyrodactylus aff. mugili Zhukov, 1970 from the greenback mullet, Chelon subviridis (Valenciennes), from the Shatt Al-Arab Estuary in southern Iraq. Fig. 2. Whole mount (composite, ventral view). Fig. 3. Male copulatory organ. Fig. 4. Hooklet. Fig.5. Anchor. Fig. 6. Anchor/bar complex. Fig. 7. Hook.

duct not observed; uterus with one or two generations of embryos (or empty); uterine pore not observed. Vitellarium absent or replaced by up to eight apparently syncytial masses located in posterior trunk and peduncle.

Haptor subcircular. Hooks similar, extrahamular; each with uniform shank having imperceptible proximal enlargement; hooklet with long fine evenly curved point, straight shaft, globose heel, tapered toe, slanting shelf; filamentous hooklet loop about $1 / 2$ shank length. Anchor delicate; anchor base with poorly developed folds and conspicuous knobs; superficial anchor root moderately long, tapered; anchor shaft slightly bowed; point recurved, elongate. Superficial bar lacking anterolateral rami, with slightly enlarged ends; superficial-bar shield short, tapered posteriorly, extending posteriorly about $1 / 3$ length of anchor shaft; deep bar variably bent, simple rod with attenuated ends inserted into anchor knobs.

Type host: So-iuy mullet, Mugil soiuy Basilewsky, now Liza haematocheila (Temminck et Schlegel), Mugilidae.

Type locality: Sea of Japan. 
Kritsky et al.: Gyrodactylus aff. mugili from mullets in Iraq

Table 1. Measurements of Gyrodactylus aff. mugili from mullets in Iraq and the Sea of Japan.

\begin{tabular}{|c|c|c|c|}
\hline & \multicolumn{3}{|c|}{ Hosts } \\
\hline & $\begin{array}{l}\text { Chelon subviridis } \\
\text { (Iraq) }\end{array}$ & $\begin{array}{l}\text { Valamugil speigleri } \\
\text { (Iraq) }\end{array}$ & $\begin{array}{l}\text { Liza haematocheila, } \\
\text { (Sea of Japan) }\end{array}$ \\
\hline \multicolumn{4}{|l|}{ Body } \\
\hline Length & $294(232-350 ; n=19)$ & $257(241-275 ; n=6)$ & $200-270$ \\
\hline Width $^{3}$ & $74(59-90 ; n=18)$ & $72(58-83 ; \mathrm{n}=6)$ & $70-80$ \\
\hline \multicolumn{4}{|l|}{ Haptor } \\
\hline Length & $70(56-82 ; \mathrm{n}=17)$ & $58(54-62 ; \mathrm{n}=6)$ & $50-56$ \\
\hline Width & $69(59-80 ; n=15)$ & $59(55-63 ; \mathrm{n}=6)$ & $62-66$ \\
\hline \multicolumn{4}{|l|}{ Pharynx } \\
\hline Anterior bulb width & $27(24-31 ; n=15)$ & $25(23-30 ; n=6)$ & - \\
\hline Posterior bulb width & $28(25-31 ; n=15)$ & $26(24-30 ; n=6)$ & - \\
\hline \multicolumn{4}{|l|}{$\mathrm{MCO}$} \\
\hline Diameter & $11(10-13 ; n=9)$ & $11(9-13 ; n=3)$ & - \\
\hline \multicolumn{4}{|l|}{ Testis } \\
\hline Length & $21(16-25 ; n=9)$ & $13(12-14 ; n=3)$ & - \\
\hline Width & $20(14-26 ; n=9)$ & $12(9-15 ; n=3)$ & - \\
\hline \multicolumn{4}{|l|}{ Germarium } \\
\hline Diameter & $26(23-30 ; n=11)$ & $19(17-22 ; n=5)$ & - \\
\hline \multicolumn{4}{|l|}{ Anchor } \\
\hline Length & $46(43-48 ; n=14)$ & $43(41-44 ; n=5)$ & $53-56$ \\
\hline \multicolumn{4}{|l|}{ Superficial bar } \\
\hline Length & $19(18-20 ; n=7)$ & $16(15-17 ; n=8)$ & $20-21$ \\
\hline \multicolumn{4}{|l|}{ Deep bar } \\
\hline Length & $10(8-12 ; n=5)$ & $9-10(n=2)$ & - \\
\hline \multicolumn{4}{|l|}{ Hook } \\
\hline Length & $26(24-27 ; n=27)$ & $24(23-26 ; n=15)$ & $29-31$ \\
\hline \multicolumn{4}{|l|}{ Hooklet } \\
\hline Length & $5(4-6 ; n=23)$ & $5(4-6 ; n=13)$ & - \\
\hline
\end{tabular}

Site of infection: Gills.

Source of current specimens: Greenback mullet Chelon subviridis (Valenciennes), Mugilidae; Shatt AlArab Estuary near Fao, Al-Basrah Province, Iraq $\left(48^{\circ} 50^{\prime} \mathrm{E}\right.$, $\left.29^{\circ} 32^{\prime} \mathrm{N}\right), 31$ March 2012; Speigler's mullet, Valamugil speigleri (Bleeker), Mugilidae; near the dam on the Shatt Al-

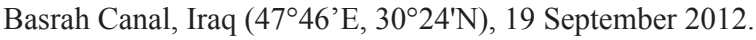

Specimens studied: 33 voucher specimens from C. subviridis, USNPC 106948, HWML 49823, NHMUK 2013.5.15.1-5; IPCAS M - 537 (two voucher specimens retained in the collections of the junior authors); 16 voucher specimens from $V$. speigleri, USNPC 106947.

Previous records as G. mugili: M. soiuy (now L. haematocheila); Sea of Japan (Zhukov 1970), Strait of Kerch between the Black Sea and Sea of Azov (Miroshnichenko and Maltsev 1998a); other records from the Azov Sea and far-eastern Russia are listed in Kostadinova (2008). Mugil cephalus Linnaeus: Strait of Kerch between the Black Sea and Sea of Azov (Miroshnichenko and Maltsev 1998a); Azov Sea (as striped mullet) (Miroshnichenko and Maltsev 1998b).

Remarks. Gyrodactylus aff. mugili is differentiated from the other species of Gyrodactylus infecting mullets by lacking anterolateral processes on the superficial bar (anterolateral processes present in G. mugelus, G. curemae and G. zhukovi) and by having delicate anchors with moderately long and tapered superficial roots (anchor base robust with a short stumpy superficial root in $G$. $x i$ amenensis).

Although morphological differences in the hook and hooklet had previously been determined to be important in differentiating species of Gyrodactylus (Malmberg 1964, Mizelle and Kritsky 1967), Zhukov (1970) failed to figure or describe in detail these structures in G. mugili. Thus, it was not possible to definitively assign the Iraqi specimens from mullets to this species or to determine their possible status as an undescribed taxon. Iraqi specimens clearly have a close affinity to G. mugili, based on the morphological similarity of their anchor/bar complexes with the respective drawing presented by Zhukov (1970). Therefore, present specimens are identified herein as $G$. aff. $m u$ gili, while recognizing that they along with G. mugili may represent a complex of morphologically similar species infecting mullets in the Indo-Pacific Region.

Miroshnichenko and Maltsev (1998a), who reported G. mugili from so-iuy mullet and the flathead grey mullet from the Azov-Black Sea Basin, provided drawings of the haptoral sclerites of the gyrodactylid, including that of the haptoral hook. Their depiction of the hooklet, while resembling that of Iraqi specimens, suggests that the structure in their specimens is slightly more robust.

It is unknown whether the gyrodactylid identified by these authors was introduced along with the so-iuy mullet 
into the Azov-Black Sea Basin from the western Pacific or if it represents a form present in the basin prior to the fish's introduction. Unfortunately, the type specimens of $G$. mugili have apparently been lost and probably no longer exist (P. Gerasev, personal communication). Thus, collection of $G$. mugili from so-iuy mullets from near the type locality in the western Pacific will be necessary to verify whether the form from the Azov-Black Sea Ba$\sin$ is G. mugili (sensu stricto), or if it represents another member of the putative species complex. Both morphological and molecular methodology will likely be necessary to define the species complex, if one actually exists on mullets within the region.

Malmberg (1970) found that water temperature, habitat (salinity levels) and host size (age) could affect the morphometrics of some of the haptoral sclerites of gyrodactylids. Similar findings were subsequently reported for these helminths by Mo et al. (1991a-c), Dávidová et al. (2005) and Olstad et al. (2009).

During the present study, gyrodactylids were collected from the brackish waters of the Al-Basrah Canal and Shatt Al-Arab Esturary in Iraq; none were obtained from the marine waters of the Arabian Gulf. Whereas minimal morphological variation occurred in specimens from the two mullet hosts, metrical differences of some structures in these gyrodactylids were noted (Table 1).

It is presently unknown whether this variation is intraspecific, resulting from the physical factors associated with the collection sites or those presented by the hosts, or if it represents species-specific features. Since fishes were not sampled from the marine environment, it is also unknown whether $G$. aff. mugili represents a fresh/brackish water form acquired by the mullets as they entered the inland waters of Iraq or if the helminths initially occurred on these host within the Arabian Gulf prior to their hosts' migration into estuarian waters.

Finally, tolerance of $G$. aff. mugili to changes in salinity as their hosts migrate to and from the inland waters of Iraq are unknown. Additional collections and studies on gyrodactylids from mullets occurring in a variety of habitats are needed to evaluate the environmental factors under which they may survive within the region.

Acknowledgements. The authors appreciate and acknowledge the assistance of Prof. Furhan T. Mhaisen (Katrineholm, Sweden), who provided much of the Iraqi literature, and Dr. Pavel Gerasev (St. Petersburg, Russia), who alerted us to the paper by Miroshnichenko and Maltsev (1998a) and provided information on the possible disposition of the type specimens of G. mugili.

\section{REFERENCES}

Abdul-Rahman N.M. 1999: [Parasites infection in fish from Garmat Ali river and its relation with food items.] M. Sc. Thesis, University of Basrah, Basrah, Iraq, 103 pp. (In Arabic.)

Al-Awadi H.M.H. 2003: Parasitic faunae (Protozoa and Monogenea) of six species of fish from Euphrates river near Kufa district (Najaf Al-Ashraf Province), Iraq. Babylon Univ. J. Pure Appl. Sci. 8: 529-532.

Al-Awadi H.M.H., Mhaisen F.T., Al-Joborae F.F. 2010: Parasitic fauna of fishes in Bahr Al-Najaf depression, mid Iraq. Bull. Iraq Nat. Hist. Mus. 11: 1-9.

Al-Daraji S.A.M. 1995: Taxonomical and ecological studies of the metazoan parasites of some marine fishes of Khor AlZubair estuary, northwest of the Arabian Gulf. Ph. D. Thesis, University of Basrah, Basrah, Iraq, 183 pp.

ALr M.D. 1985. Observations on lernaeosis and gyrodactylosis in carp fingerlings raised in ponds. J. Biol. Sci. Res. 16: 125-132.

Ali M.D., Shaaban F. 1984: Some species of parasites of fresh water fish raised in ponds and in Tigris - Al-Tharthar canal region. Seventh Sci. Conf. Iraqi Vet. Med. Assoc., Mosul, 23-25 October 1984, abstracts of papers pp. 44-48.

AL-JANAE'E A.M.S. 2010: [Parasites of some Iraqi fishes in two localities varied in their trophic levels in inland water of Basrah.] M. Sc. Thesis, College of Agriculture, University of Basrah, Basrah, Iraq, 228 pp. (In Arabic.)

Al-Nasiri F.S., Mhaisen F.T., Al-Nasiri S.K. 2003: Parasites of the grey mullet Liza abu in a man-made lake at Baghdad region. Iraqi J. Agric. (Spec. Issue) 8: 133-140.

AL-SA'ADI B.A.-H.E. 2007: [The parasitic fauna of fishes of Euphrates River: applied study in Al-Musaib City.] M. Tech. Thesis, Al-Musaib Technical College, Al-Musaib, Iraq, 102 pp. (In Arabic.)
Al-SAlim N.K., JoRi M.M. 2000: [Study of the parasites of two mugilid fish and the effect of some on the blood parameters (1-m0n0genen).] Mar. Mesopotamica 15: 505-514. (junior author's name misspelled Juri in the publication). (In Arabic.)

Al-Zubaidy A.B. 2007: First record of three monogenic [sic!] parasite species from Iraqian freshwater fishes. J. King AbdulAziz Univ., Mar. Sci. 18: 83-94.

Bakke T.A., Harris P.D., Jansen P.A., Hansen L.P. 1992: Host specificity and dispersal strategy in gyrodactylid monogeneans, with particular reference to Gyrodactylus salaris (Platyhelminthes, Monogenea). Dis. Aquat. Org. 13: 63-74.

Balasem A.N., Mhaisen F.T., Al-Jawda J.M., Asmar K.R., ADDAY T.K. 2002: [Parasitic fauna of some fishes in northern sector of Saddam's River at Al-Mahmoodiya City, Iraq.] AlTharwa Al-Samakia 21: 43-48. (In Arabic.)

Bannai M.A.A., Al-Daraji S.A.M., Jarallah H.M., Bannal J.A.A., Wanes A.K. 2005: Helminth parasite of grey mullet Liza subviridis (Val., 1836) from Khor Abdulah, Arabian Gulf. Mar. Mesopotamica 20: 311-316.

Coad B.W. 2010: Freshwater Fishes of Iraq. Pensoft Publishing, Sofia \& Moscow, 274 pp.

Conroy G., Conroy D.A. 1985: Gyrodactylosis in silver mullet (Mugil curema Val.) from Venezuelan coastal waters, and a description of Gyrodactylus curemae n. sp. Riv. Ital. Piscicult. Ittiopatol. 20: 140-147.

Dávidová M., Jarkovský J., Matějusová I., Gelnar M. 2005: Seasonal occurrence and metrical variability of Gyrodactylus rhodei Žitňan 1964 (Monogenea, Gyrodactylidae). Parasitol. Res. 95: 398-405.

Dmitrieva E.V., Gerasev P.I., Gibson D.I., Pronkina N.V., GALLI P. 2012: Descriptions of eight new species of Ligophorus 
Euzet et Suriano, 1977 (Monogenea: Ancyrocephalidae) from Red Sea mullets. Syst. Parasitol. 81: 203-237.

EschmeYer W.N. 2013: Catalog of Fishes. research.calacademy. org/research/ichthyology/catalog/fishcatmain.asp, 2/2013.

Eschmeyer W.N., Fong J.D. 2013: Catalog of Fishes. Species by Family/Subfamily. research.calacademy.org/research/ichthyology/catalog/speciesbyfamily.asp, 2/2013.

Froese R., Pauly E. (Eds.) 2013: FishBase. World Wide Web electronic publication, www.fishbase.org, 2/2013.

Humason G.L. 1979: Animal Tissue Techniques. Fourth Edition. W. H. Freeman \& Comp., San Francisco, 661 pp.

Kostadinova A. 2008: A checklist of macroparasites of Liza haematocheila (Temminck et Schlegel) (Teleostei: Mugilidae). Parasites \& Vectors 1: 48.

Kritsky D.C., Leiby P.D., Kayton R.J. 1978: A rapid stain technique for the haptoral bars of Gyrodactylus species (Monogenea). J. Parasitol. 64: 172-174.

Kritsky D.C., Mizelle J.D. 1968: Studies on monogenetic trematodes. XXXV. Some new and previously described North American species of Gyrodactylus. Amer. Midl. Nat. 79: 205215.

Malmberg G. 1964: Taxonomical and ecological problems in Gyrodactylus (Trematoda, Monogenea). In: R. Ergens and B. Ryšavý (Eds.), Parasitic Worms and Aquatic Conditions. Proceedings of a Symposium held in Prague, October 29-November 2, 1962, Publ. House of the Czechoslovak Academy of Sciences, Prague, pp. 203-230.

Malmberg G. 1970: The excretory systems and the marginal hooks as a basis for the systematics of Gyrodactylus (Trematoda, Monogenea). Ark. Zool. 23: 1-235 + 8 Plts.

Mhaisen F.T., Al-Khateeb G.H., Balasem A.N., Al-Shaikh S.M.J., Al-Jawda J.M., Mohammad-Ali N.R. 2003b: Occurrence of some fish parasites in Al-Madaen drainage network, south of Baghdad. Bull. Iraq Nat. Hist. Mus. 10: 39-47.

Mhaisen F.T., Al-Yamour K.Y., Allouse S.B. 1995: Parasites of some freshwater fishes from Tigris River at Al-Rashidia, north of Baghdad, Iraq. Arquiv. Mus. Bocage, Nov. Sér. 2: 547-554.

Mhaisen F.T., Balasem A.N., Al-Khateeb G.H., Asmar K.R. 2003a: Recording of five monogenetic trematodes for the first time from fishes of Iraq. Bull. Iraq Nat. Hist. Mus. 10: 31-38.

Miroshnichenko A.I., Maltsev V.N. 1998a: [Species of Gyrodactylus (Monogenea, Gyrodactylidae) from soiuy mullet new for the Azov-Black Sea basin.] Proc. South. Res. Inst. Mar. Fish. Oceanogr. 44: 116-125. (In Russian.)

Miroshnichenko A.I., Maltsev V.N. 1998b: [On monogenean fauna of golden mullet and striped mullet in the Azov

Received 25 February 2013
Sea.] In: A.F. Alimov (Ed.), Systematics and Phylogeny of Plathelminthes, a symposium held in St. Petersburg, Russia, 3-5 November 1998. Zoological Institute, Russian Academy of Sciences, St Petersburg, pp. 68-69. (In Russian.)

Mizelle J.D., Kritsky D.C. 1967: Studies on monogenetic trematodes. XXX. Five new species of Gyrodactylus from the Pacific tomcod, Microgadus proximus (Girard). J. Parasitol. 53: 263-269.

Mo T.A. 1991a: Seasonal variations of opisthaptoral hard parts of Gyrodactylus salaris Malmberg, 1957 (Monogenea: Gyrodactylidae) on parr of Atlantic salmon Salmo salar L. in the River Batnfjordselva, Norway. Syst. Parasitol. 19: 231-240.

Mo T.A. 1991b: Variations of opisthaptoral hard parts of Gyrodactylus salaris Malmberg, 1957 (Monogenea: Gyrodactylidae) on rainbow trout Oncorhynchus mykiss (Walbaum, 1792) in a fish farm, with comments on the spreading of the parasite in southeastern Norway. Syst. Parasitol. 20: 1-9.

Mo T.A. 1991c: Variations of opisthaptoral hard parts of Gyrodactylus salaris Malmberg, 1957 (Monogenea: Gyrodactylidae) on parr of Atlantic salmon Salmo salar L. in laboratory experiments. Syst. Parasitol. 20: 11-19.

Mohammad-Ali N.R., Balasem A.N., Mhaisen F.T., Salih A.M., WAHEed I.K. 1999: Observations on the parasitic fauna in Al-Zaafaraniya fish farm, south of Baghdad. Veterinarian 9: 79-88.

Olstad K., Bachmann L., Bakke T.A. 2009: Phenotypic plasticity of taxonomic and dignostic structures in gyrodactylosiscausing flatworms (Monogenea, Platyhelminthes). Parasitology 136: $1305-1315$.

Rawson M.V., JR. 1973: Two new species of Gyrodactylus (Trematoda: Monogenea) from the Georgia coast. Proc. Helminthol. Soc. Wash. 40: 180-183.

Soo O.Y.M., Liм L.H.S. 2012: Eight new species of Ligophorus Euzet \& Suriano, 1977 (Monogenea: Ancyrocephalidae) from mugilids off Peninsular Malaysia. Raffles Bull. Zool. 60: 241264.

Thomson J.M. 1997: The Mugilidae of the world. Mem. Queensland Mus. 41: 457-562.

TRIPATHi Y.R. 1959: Monogenetic trematodes from fishes of India. Ind. J. Helminthol. 9: 1-149.

Zhang J., YANG T., LiU L. et AL. 2001: Monogeneans of Chinese Marine Fishes. Agriculture Press, Beijing, 400 pp. (In Chinese.)

Zнuкоv E.V. 1970: [New species of trematodes and monogeneans from marine fishes of Posjet Bay (the Sea of Japan)]. Parazitologiya 4: 321-326. (In Russian.)

Accepted 14 May 2013 